\title{
Human resources for health strategies: the way to achieve universal health coverage in the Islamic Republic of Iran
}

\author{
Gholamhossein Salehi Zalani ${ }^{1}$, Roghayeh Khalilnezhad ${ }^{2}$, Elmira Mirbahaeddin ${ }^{3}$, Azad Shokri ${ }^{4,5}$, Tahereh Kashkalani ${ }^{1}$, Mahboubeh Bayat ${ }^{6}$
}

${ }^{1}$ Center for Health Human Resources Research \& Studies, Ministry of Health and Medical Education, Tehran, Islamic Republic of Iran. ${ }^{2}$ Health Management and Economics Research Center, Iran University of Medical Sciences, Tehran, Islamic Republic of Iran ${ }^{3}$.Telfer School of Management, University of Ottawa, Ontario, Canada. ${ }^{4}$ Social Determinants of Health Research Center, Kurdistan University of Medical Sciences, Sanandaj, Islamic Republic of Iran. ${ }^{5}$ Department of Health Services Management, School of Public Health, Tehran University of Medical Sciences, Tehran, Islamic Republic of Iran. ${ }^{6}$ Gerash University of Medical Sciences, Gerash, Islamic Republic of Iran. (Correspondence to: M. Bayat: h.bayat57@gmail.com).

\begin{abstract}
Background: It is impossible to achieve universal health coverage (UHC) without an adequate, competent and motivated workforce.

Aims: The study aimed to describe how the Iranian health sector has formulated its human resources strategies to achieve UHC.

Methods: This was a qualitative study using a conceptual framework approach to content analysis. Primary data were gathered through expert focused group discussions and document analyses. Both transcribed discussions and the selected documents were analysed using in-depth thematic analysis. A conceptual framework from the Global Health Workforce Alliance was used for content analysis and to draft and develop the strategies. The framework suggested five human resources for health $(\mathrm{HRH})$ pathways to achieve UHC aspects structured according to availability, accessibility, acceptability and quality.

Results: Thirty strategies were formulated for Iranian HRH. Eleven of the developed strategies were related to the field of education and training, such as development of new required academic disciplines; balancing university admissions based on workforce requirements; and enrolling local students from deprived and underserved areas. Ten of the developed strategies were structured under the workforce accessibility dimension.

Conclusions: Strategies for HRH were formulated by adopting a comprehensive, scientific and collaborative approach to ensure alignment with the country's health system priorities and Global Strategy on Human Resources for Health to overcome health workforce challenges.
\end{abstract}

Keywords: human resources for health, strategy, formulation, universal health coverage, Islamic Republic of Iran

Citation: Zalani GS; Khalilnezhad R; Mirbahaeddin E; Shokri A; Kashkalani T; Bayat M. Human resources for health strategies: the way to achieve universal health coverage in the Islamic Republic of Iran. East Mediterr Health J. 2018;24(9):846-854. https://doi.org/10.26719/2018.24.9.846

Received: 02/10/17; accepted: 14/08/18

Copyright (c) World Health Organization (WHO) 2018. Some rights reserved. This work is available under the CC BY-NC-SA 3.0 IGO license https://creativecommons.org/licenses/by-nc-sa/3.0/igo

\section{Introduction}

The World Health Organization (WHO) has emphasized that it would be almost impossible to provide universal health coverage (UHC) without an adequate, motivated and professional workforce (1). Therefore, health systems have become responsible for attracting, preparing, deploying and retaining highly skilled workforces to provide access to appropriate, timely and effective care, with the aim of achieving UHC goals (2-6). Achievement of these goals requires national commitments to develop human resources for health $(\mathrm{HRH})$ strategies.

Although HRH have always been under scrutiny, in most cases, unresolved problems remain due to a fragmented approach to $\mathrm{HRH}$ (7). Alignment of $\mathrm{HRH}$ strategies with health sector policies requires an integrated perspective of the health sector and its components (8). Achievement of UHC relies on focusing on HRH as a strategy for health system reform (9). In 2008, the Global Health Workforce Alliance (GHWA) initiated global forums on $\mathrm{HRH}$ for the first time and called for urgent and sustained action to resolve the critical shortage of health workers around the world. GHWA recognized the health workforce as a high leverage point in service delivery and policy implementation (10-12), and created an opportunity to mobilize diverse health stakeholders for the formulation of $\mathrm{HRH}$ strategies towards achieving UHC. These forums provided the groundwork for reaching a global $\mathrm{HRH}$ strategy by 2030. At the third forum in 2013 in Recife, Brazil, GHWA suggested a model that was an advocacy instrument to facilitate policy dialogue for mapping the most effective and evidence-informed HRH strategies and their interrelatedness. The GHWA model included 2 parts. First, a UHC framework of availability, accessibility, acceptability and quality (AAAQ) that acts as a bridge between $\mathrm{HRH}$ actions and UHC to ensure vertical integration of $\mathrm{HRH}$ strategies. The AAAQ concept was initiated by WHO in the 1960 s to evaluate health system performance (13). Second, there were 5 coordinated pathways of $\mathrm{HRH}$ : education; skills mix; health labour markets; incentives and retention; and cross-cutting actions. These pathways mean that stand-alone interventions would not be effective and they should be integrated horizontally. For 
example, employing a new, competent workforce needs to be in conjunction with its motivation and development strategies.

However, it is essential in the GHWA model to define appropriate HRH strategies based on the recommended HRH pathways to reach the intended targets of UHC. Figure 1 shows this model briefly (14-16), illustrating its AAAQ aspects. It shows that some vertical and horizontal elements are compulsory to generate integration among the strategies (17). This model is globally accepted by 57 national governments, mostly from low- and middleincome countries, which have formed their strategies based on the model (18).

Development of HRH strategies in the Islamic Republic of Iran does not have a long history. A strategic plan for HRH was developed for the first time in 2003 by the Iranian Ministry of Health and Medical Education (MOHME) (19); however, it had little relevance to the health system goals. Subsequently, in 2010 and 2011, several projects analysed upstream national documents and extracted HRH-related themes in order to identify the principle directions and challenges (20). In 2012, HRH strategies were developed in line with the Iranian health system reform plan. Unfortunately, these strategies were not implemented successfully due to lack of advocacy among different levels and lack of a systematic evaluation framework (8). The present study aimed to show how recent Iranian HRH strategies were developed for the Third Global Forum on Human Resources for Health in Recife, 2013.

\section{Methods}

This was a qualitative study that used a conceptual framework approach to content analysis to investigate formulating HRH strategies in the Islamic Republic of Iran). The framework used in this study was the GHWA model. To start, two major sources of evidence were used: expert focused group discussions (FGDs) and document review. Multiple sources of data allowed access to a broader range of inputs for producing valid results (21).

For FGDs, purposeful sampling was used to select external and internal stakeholders in the Iranian MOHME $(22,23)$. The participants were invited through an official letter that explained the purpose, goals and stages of the study (Table 1). Three face-to-face FGDs were facilitated by two of the researchers (Table 2). FGDs guided by the adopted WHO conceptual framework and the participants' views about HRH issues were discussed during the sessions. Field notes made during the FGDs and all discussions were audiotaped and transcribed for analysis. The FGDs lasted an average of three hours. After each session, the topics were summarized and the results were presented to the participants at the beginning of the next FDG. The discussion output after the second FGD was sent to the participants in a textual form and their final comments were received.

Another source of data was analysis of documents. All national policy documents were identified and evaluated for relevancy by two researchers (Table 2). In this phase, eight technical documents were selected and each was carefully and independently reviewed by two researchers

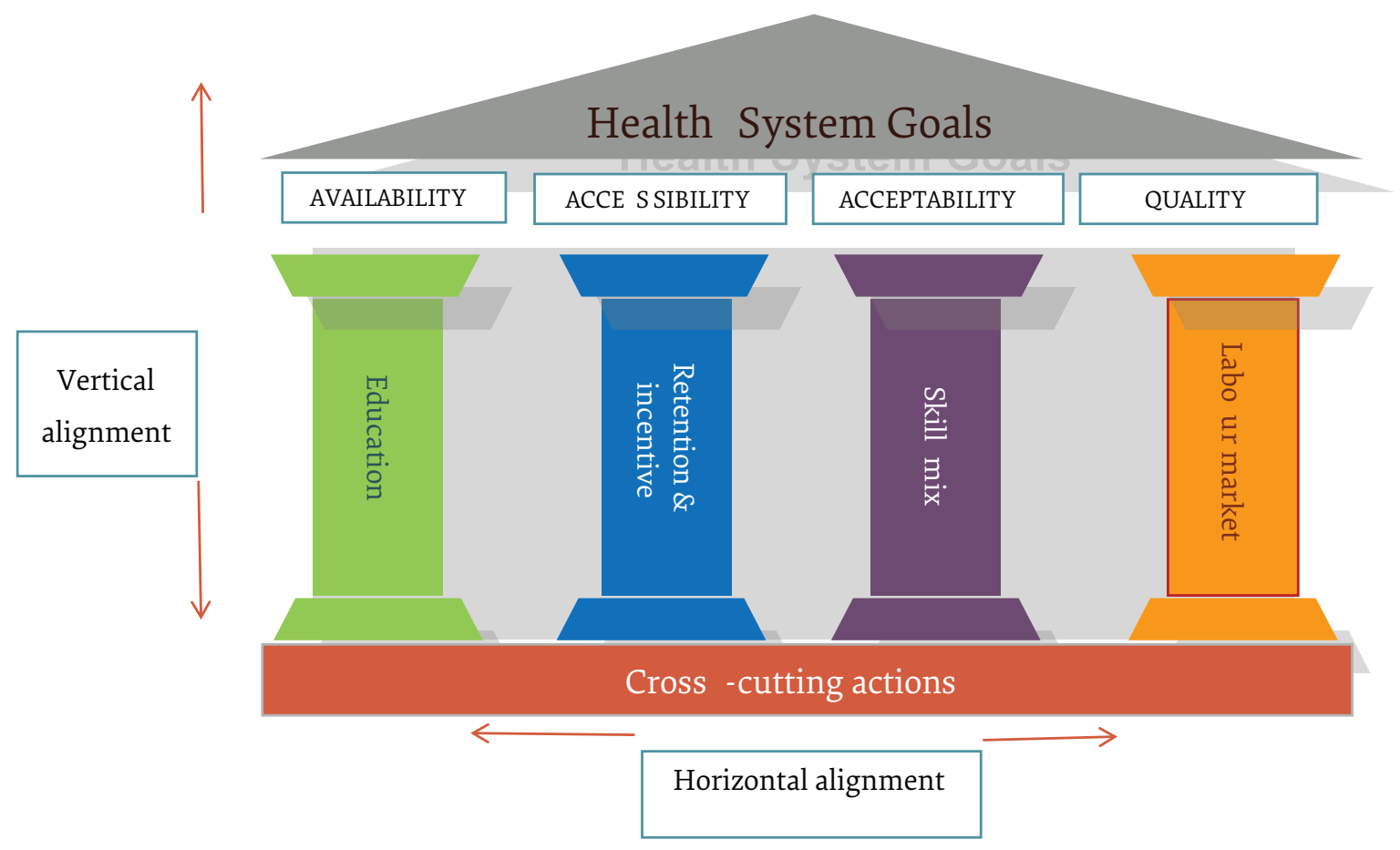




\begin{tabular}{|c|c|c|c|c|}
\hline No. & Sex & Occupation & Affiliation & Credentials \\
\hline 1 & Male & HRM expert & Individual & $\mathrm{PhD}$ \\
\hline 2 & Female & HRM expert & Individual & MS \\
\hline 3 & Female & HRM expert & Individual & MS \\
\hline 4 & Male & HRM expert & Individual & $\mathrm{PhD}$ \\
\hline 5 & Female & HRM expert & Individual & $\mathrm{PhD}$ \\
\hline 6 & Male & HRM expert & Individual & MS \\
\hline 7 & Female & Technical expert & $\mathrm{MoH}$ & BA \\
\hline 8 & Male & Technical expert & $\mathrm{MoH}$ & MS \\
\hline 9 & Male & Technical expert & $\mathrm{MoH}$ & MS \\
\hline 10 & Female & Technical expert & $\mathrm{MoH}$ & MS \\
\hline 11 & Female & Technical expert & $\mathrm{MoH}$ & GP \\
\hline 12 & Male & Technical expert & $\mathrm{MoH}$ & $\mathrm{PhD}$ \\
\hline 13 & Male & Technical expert & $\mathrm{MoH}$ & BA \\
\hline 14 & Female & Technical expert & $\mathrm{MoH}$ & MS \\
\hline 15 & Female & Technical expert & $\mathrm{MoH}$ & GP \\
\hline 16 & Female & Technical expert & $\mathrm{MoH}$ & MA \\
\hline 17 & Male & HR manager & Gilan University & MS \\
\hline 18 & Male & HR manager & Tehran University & $\mathrm{PhD}$ \\
\hline 19 & Male & HR manager & Zanjan University & MS \\
\hline 20 & Female & HR manager & $\begin{array}{l}\text { Mazandaran } \\
\text { University }\end{array}$ & MS \\
\hline 21 & Male & HR manager & Iran University & $\mathrm{PhD}$ \\
\hline 22 & Male & HR manager & Isfahan University & MS \\
\hline 23 & Male & HR manager & Tabriz university & $\mathrm{PhD}$ \\
\hline 24 & Male & HR manager & $\begin{array}{l}\text { Rafsanjan } \\
\text { university }\end{array}$ & GP \\
\hline 25 & Male & HR manager & Zahedan university & MS \\
\hline 26 & Male & Deputy Minister & $\mathrm{MoH}$ & Medical specialist \\
\hline 27 & Male & Deputy Minister & $\mathrm{MoH}$ & $\mathrm{PhD}$ \\
\hline 28 & Male & Director & $\begin{array}{l}\text { Tehran Emergency } \\
\text { Center }\end{array}$ & Medical specialist \\
\hline 29 & Male & Director & $\begin{array}{l}\text { Iranian Blood } \\
\text { Transfusion } \\
\text { Organization }\end{array}$ & $\mathrm{PhD}$ \\
\hline
\end{tabular}

Abbreviations: $G P=$ General Practitioner; HRM = Human Resources Management; $M o H=$ Ministry of Health

\begin{tabular}{llllll}
\hline \multicolumn{7}{l}{ Table 2 Personal characteristics of researchers and facilitators } & & \\
\hline No. & Sex & Credentials & Occupation & Experience or training & Role in FGD and coding \\
\hline 1 & Male & $\mathrm{PhD}$ & HRM expert at $\mathrm{MoH}$ & 27 years of experience in HR & Document analyzing \\
2 & Female & $\mathrm{PhD}$ candidate & HRM expert at $\mathrm{MoH}$ & 15 years of experience in HR & Facilitator of FGs \\
3 & Female & $\mathrm{PhD}$ candidate & HRM expert at $\mathrm{MoH}$ & 13 years of experience in HR & Facilitator of FGs \\
4 & Female & $\mathrm{PhD}$ candidate & HRM expert at $\mathrm{MoH}$ & 12 years of experience in HR & Data coder \\
5 & Male & $\mathrm{PhD}$ candidate & HRM expert at $\mathrm{MoH}$ & 4 years of experience in HR & Data coder \\
6 & Female & $\mathrm{MS}$ & HRM expert at $\mathrm{MoH}$ & 3 years of experience in HR & Document analysis \\
\hline
\end{tabular}

Abbreviations: FGD = Focus Group Discussion; HRM = Human Resources Management; $M$ oH = Ministry of Health. 


\section{to assure the quality.}

The transcribed FDGs, with final corrections based on comments, and selected documents were analysed by two researchers (Table 2) using an in-depth framework method for content analysis by MAXQDA version 10 (qualitative data analysis software). For analysis, after transcription and familiarization with the whole content, we applied the conceptual framework of the study as a coding system for indexing transcripts and then charted the extracted codes and categories into the matrix of the AAAQ and HRH pathways. This analysis method also concurred with the components of the conceptual framework (WHO systematic template of AAAQ and $\mathrm{HRH}$ pathways). To verify the trustworthiness of the results, we used peer debriefing as well as member-checking by at least two members of the research team at each step. The FGDs provided in-depth methodological descriptions for the participants and all topics discussed were carefully documented. The analysis revealed 40 strategies (codes) from which 30 were confirmed through the third FGD session with the selected participants (Figure 2).

\section{Results}

We identified 30 themes through the multiple-methods approach according to the five $\mathrm{HRH}$ pathways structured by AAAQ. The themes were organized into the model by allocating 11 strategies in education, 5 in retention and incentives, five in skill mix, four in labour markets pathways and five in cross-cutting actions. A review of the strategies showed that they also properly fitted into the AAAQ structure aiming to achieve UHC. In terms of AAAQ structure, four strategies fitted in availability, 10 in accessibility, six in acceptability and 5 in quality (Figure 3). Colour codes presented in Figure 3 shows how each of the developed strategies related to the AAAQ aspects.

Strategies in the education pathway indicated that new academic disciplines required to be developed, and university admissions should be mostly from local students of deprived and underserved areas. Besides, the entries must be based on workforce status that is defined by workforce shortage, balance and excess. It is necessary to provide the financial resources and other supports to ensure local recruitment and essential training to upgrade knowledge and skills among frontline health workers. To estimate the required resources for training and consequent allocation in annual operating budgets, the per capita method was useful to calculate required funds to train the workforce. With regard to workforce provision in underserved areas, legal obligations of education in medical disciplines were proposed to recruit medical specialists and general practitioners to work in required areas.

Figure 2 Human resources for health (HRH) strategies formulation process

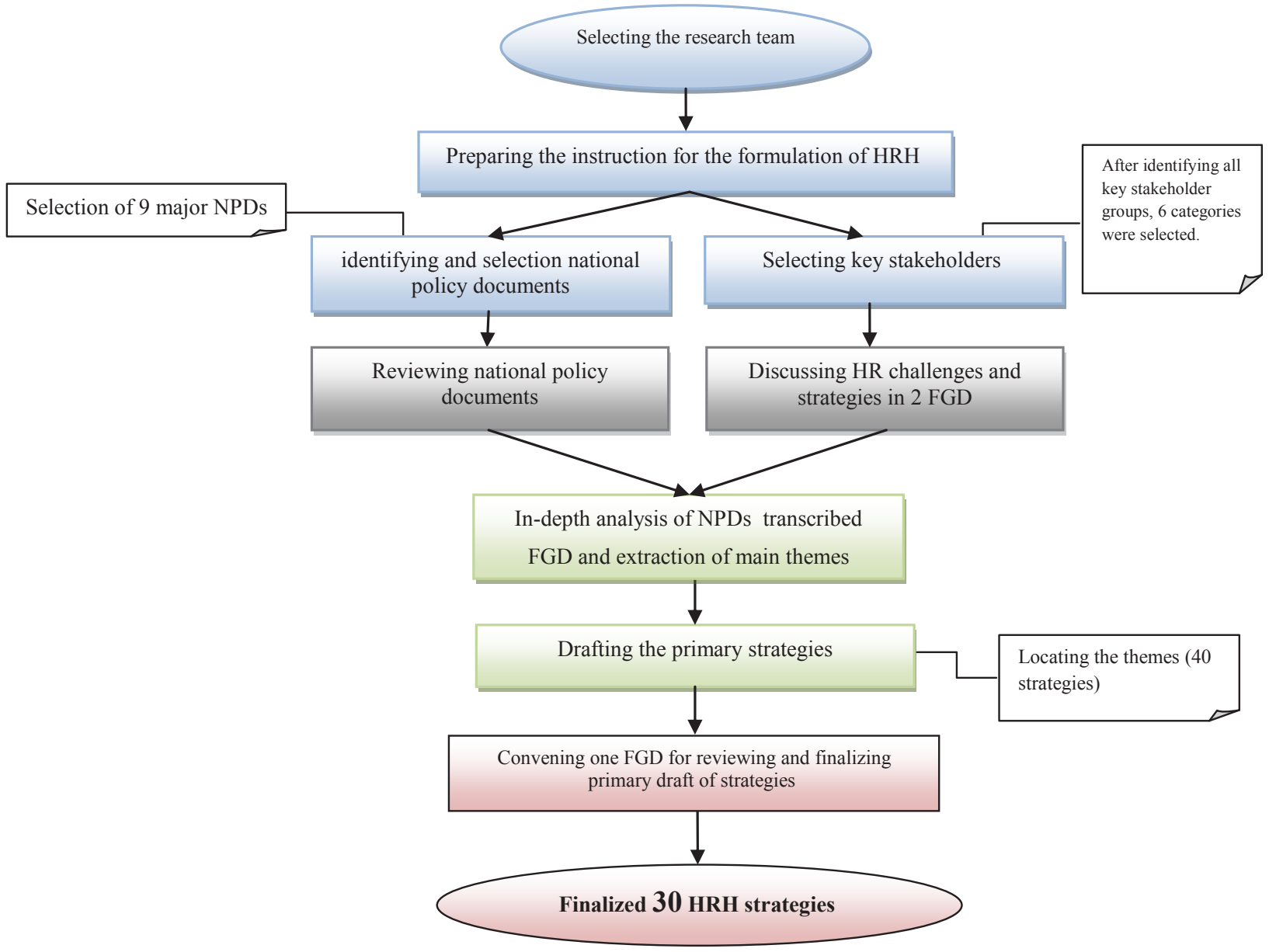




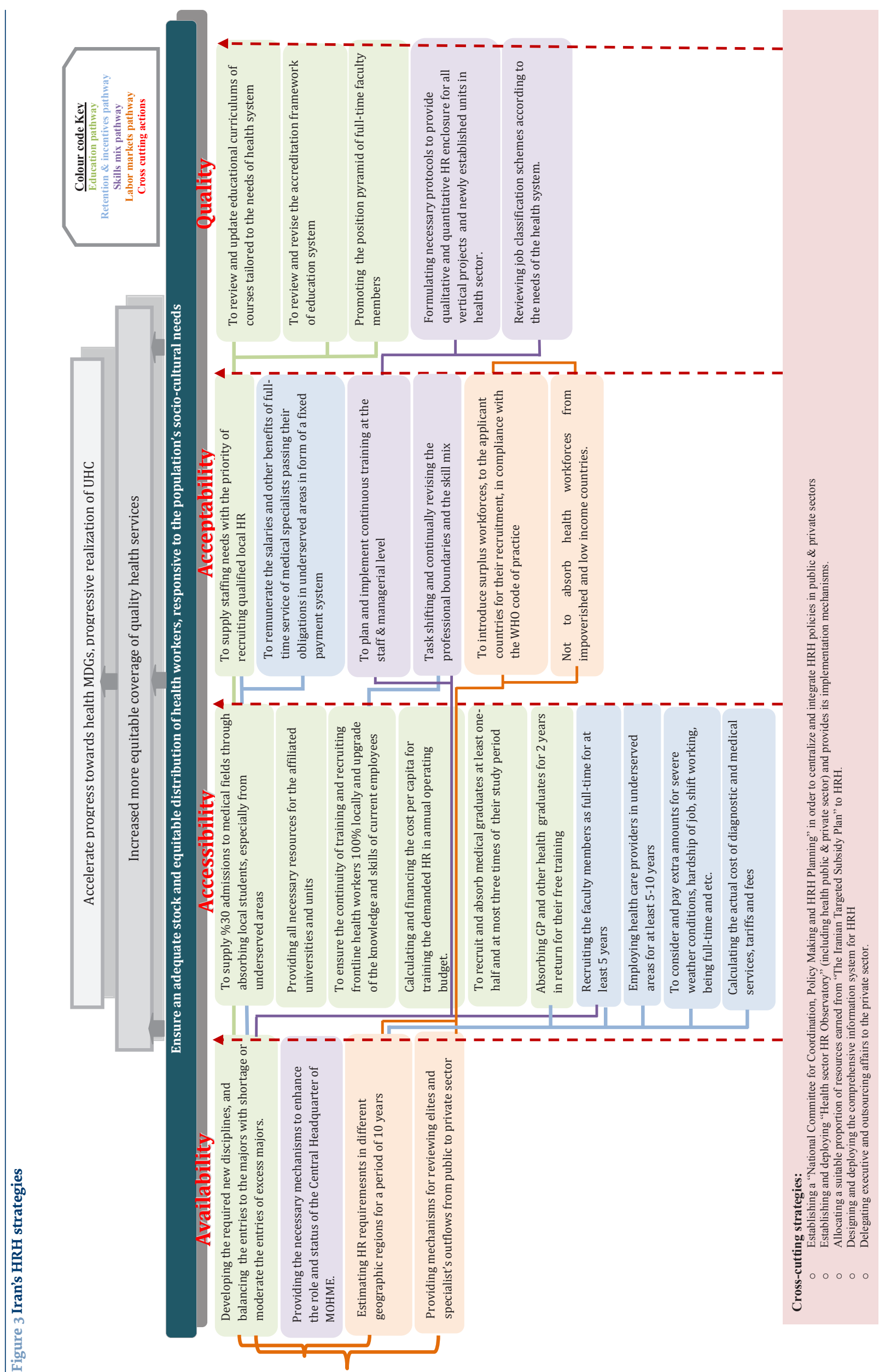


To improve retention and incentives, the findings suggested that we should recruit university faculty members with a full-time contract for at least five years and to employ other providers in underserved areas for five to ten years. Since the deprived areas suffer from severe weather conditions, incentive packages should be developed to include extra payments addressing the unpleasant weather, hardship of the job, working in shifts, and being a full-time employee. Moreover, the actual cost of diagnostic and medical treatment must be recalculated to reach authentic medical tariffs and service fees for medical specialists. For the skill mix pathway, the strategies identified continuous training as an important factor to improve competencies of both the staff and managers. With growing interest in interprofessional practice, the strategies suggested task shifting and revision in professional boundaries and skill mix, as well as a review of job classification schemes indicating the needs of the health system. It appears to be essential to develop HR attachment protocols for all vertical health projects.

Labour market strategies mainly addressed estimation of health workforce requirements for a period of 10 years. The workforce midterm plan will show the health system demand and surplus of medical and paramedical workforces that could be introduced to other countries on demand. Ethically, the strategies promoted should not recruit from impoverished and low-income countries, in accordance with the WHO Global Code of Practice on the International Recruitment of Health Personnel. New mechanisms are required to review the outflow of elite and specialist workers from the public to private sector.

Cross-cutting strategies sought integration of public and private sector HRH policy-making and planning. Strategies urged delegation and outsourcing of executive affairs to the private sector. The strategies also found that this integration requires establishing a national committee and deploying an HRH observatory. In addition, a suitable proportion of the Iranian Targeted Subsidy Plan should be allocated to the HRH plans. However, the main prerequisite would be design and development of a comprehensive $\mathrm{HRH}$ information system.

\section{Discussion}

This study showed how the Islamic Republic of Iran developed its health workforce strategies for applying the comprehensive framework provided by the GHWA. This framework had the advantage of previous advocacy in the Islamic Republic of Iran due to its preparation for the Third HRH Forum in Recife, and it was considered acceptable and comprehensible for the further contribution of the stakeholders. This model created cohesion among Iranian strategies, because it used a systematic approach that clarified and covered performance gaps of current HRH (8).

In terms of the content of developed strategies, the focus was primarily on the accessibility, acceptability and quality of the services provided by HR, rather than the availability of workforces. The main challenge of HR management in the Islamic Republic of Iran has been retention and maintenance of the health workforce, especially in deprived and underserved areas, and this has significantly affected accessibility to health services (8). This is consistent with Indonesian HRH policies struggling with the issue of accessibility to health workers as one of the major challenges facing the country (24).

To improve equal access to health workers, the main strategic focus was on local recruitment and retention of the workforce. For example, Behvarz (rural health workers), only recruited locally. For this purpose, local applicants are admitted to Behvarzy high schools as students, and after two years of education and training, they are permanently recruited as Behvarz. Behvarz continuously improve their knowledge and professional skills through follow-up and continuous in-service training. This is specifically in line with global HRH milestones for 2030 to reduce inequalities in access to health workers (17). Other countries have recognized this issue and have devised policies to train, recruit and retain their community health workers (18).

In the Islamic Republic of Iran, most problems of health workforce retention are related to physicians, especially specialists in underserved regions, due to lack of facilities and living conditions. For this reason, retention strategies are oriented towards compulsory service in underserved areas, and rationalization of health service tariffs and remuneration. Similarly, in Sudan HRH strategies are focused on loss of physicians due to migration (24). The Global HRH Strategy 2030 confirms these trends and suggests that countries should regulate working conditions and operations in all healthrelated sectors, and implement motivational measures to achieve national alignment with public sector health goals (25).

The present study showed development of policies to recruit local students, especially those from deprived areas, based on particular provincial needs. The Global HRH Strategy 2030 also suggests aligning educational investment with future government policies for local employment and adopting innovative financial packages as incentives for retention. It also recommends applying cost-effective methods to harness different health cadres and skill mixes $(25,26)$.

To promote workforce availability while considering the dynamic nature of $\mathrm{HRH}$ needs and changes in national policies, the strategies in the present study focused on establishing new required disciplines, longterm workforce planning and retaining elite workers in the public health system (16). Most countries struggle to achieve their health system goals (27), and find health workforce planning problematic in terms of balancing supply and demand in the health workforce (28).

In the acceptability measure, the HRH strategies discussed provision of acceptable services by an acceptable workforce in an acceptable way. Therefore, the strategies considered staffing by competent workers, training and 
empowerment of staff, and revision of the professional boundaries and skill mix. Organisation for Economic Cooperation and Development countries also have policies such as team-based training and problem-based learning to promote current skills of different health professionals (29). Changing professional boundaries is an innovative strategy by which the Iranian health system could improve its workforce skill mix and meet the growing workforce demand and anticipated shortage of health workers (30). Other aspects of acceptability that were not considered in this study include gender, age, culture and dialect of the health workforce (31).

Although the workforce plays the most important role in delivering health services, their knowledge and competency are not regularly updated or they remain inadequate because they have not improved consistently with the development of knowledge, technology and other changes such as demographic characteristics and disease patterns (32). These problems have been considered by revising curricula and job classifications, and establishing accreditation strategies. In this regards, one study has strongly recommended that all countries move towards aligning accreditation, licensing and certification of education systems with UHC goals (32).

The cross-cutting strategies for the Islamic Republic of Iran, such as the necessity for reinforcing information systems or financial investment, are similar to the $\mathrm{HRH}$ policies in other middle and low-income countries with common HR challenges $(9,18)$. The cross-cutting strategies include design and deployment of a comprehensive $\mathrm{HRH}$ information system that covers the whole heath labour market and produces a standardized health workforce information system. Likewise, the Global HRH Strategy 2030 has a particular focus on enhancing $\mathrm{HRH}$ information systems for advanced analysis and strength of capacities for communication to policy-makers. Additionally, outsourcing and delegating executive and administrative tasks to the private sector is the main strategy to reinforce the private sector while preserving government authority.
Overall, the first step to achieve UHC is to provide the required health workforce. Essential interventions to ensure HRH availability have been implemented in the Islamic Republic of Iran; therefore, the current national policies and priorities of the health sector have focused on accessibility strategies.

The present study had some limitations. It was not possible to consider all feasible alternatives that could overcome the current challenges; therefore, there may have been limitations in the comprehensiveness of the developed strategies. To overcome this limitation, we used information from multiple sources to devise the most appropriate strategies. Moreover, since group discussions can be difficult to steer and control, we tried to decrease these limitations by balancing the diversity of the participants based on expertise and organizational position. Furthermore, identification of the right stakeholders might have been biased and it was possible that we missed some valuable experts to invite to FGDs.

\section{Conclusion}

Iranian HRH policies appear to be well aligned with the UHC goals, at least in principle. Measurement of the effectiveness of these strategies requires full implementation and evaluation of results, which will be examined in future studies. To align with global health goals, every country should engage critical stakeholders, including government, professional bodies, and academics to formulate appropriate strategies to overcome $\mathrm{HRH}$ challenges. Deep identification of national conditions and prerequisites such as historical, economic and political context, health needs, rules and regulations are essential to an evidence-based policy-making process. Such a process can recognize transformative actions and address existing gaps in HRH. However, for the best-written strategies to reach their targets needs sustainable funding, long-term governmental vision, political commitment, and accountability.

Funding: None.

Competing interests: None declared.

\section{La perception des besoins par les personnels de soins de santé au Liban : un pas en avant vers une planification éclairée des ressources humaines et du développement professionnel}

\section{Résumé}

Des recherches ont déjà été menées dans plusieurs pays au regard des compétences requises pour gérer de façon efficace les organismes de soins de santé. Pourtant, peu de données sont disponibles concernant les compétences et les domaines de connaissances qui font actuellement défaut parmi les personnels de soins de santé travaillant dans des environnements disposant de ressources limitées.

Objectif : L'objectif de la présente étude était d'évaluer la perception des besoins par les personnels de soins de santé au Liban.

Méthodes : Nous avons mené une étude exploratoire suivant la méthode de Delphi, faisant intervenir deux comités de professionnels de soins de santé et comportant une enquête nationale menée auprès de directeurs d'établissements hospitaliers afin d'évaluer les compétences nécessaires et les métiers et spécialités faisant défaut dans le secteur des soins de santé.

Résultats : Les cinq principaux domaines où se fait sentir le besoin en compétences et en connaissances sont les suivants : 
le professionnalisme, la gestion fondée sur des données probantes, la planification stratégique, la gestion et l'amélioration de la qualité et les compétences en communication. La gestion et la technologie de l'information ont été mises en avant dans les hôpitaux urbains ainsi que par les deux comités de professionnels. Les professionnels de soins de santé se sont déclarés prêts à suivre des cours de formation continue. Les hôpitaux ont indiqué la disponibilité de moyens financiers et leur volonté de collaborer avec les établissements d'enseignement afin de faire bénéficier leur personnel de formations et de sessions d'éducation continue.

Conclusion : Nos résultats préparent le terrain pour des recherches futures portant sur les problèmes des personnels de soins de santé au Liban et parlent en faveur d'une planification des ressources humaines fondée sur des données probantes. Ils pourraient éclairer l'élaboration de politiques nationales et locales dans le pays, capables de répondre aux besoins en ressources humaines du système de soins de santé en vue de satisfaire la demande aux niveaux régional et national. Les universités, les syndicats de professionnels et les organisations non gouvernementales pourraient exploiter ces résultats afin d'élaborer des programmes de formation continue et des programmes diplômants intégrant les compétences essentielles requises pour les personnels de soins de santé.

$$
\begin{aligned}
& \text { استراتيجيات الموارد البشرية الصحية: السبيل إلى تحقيق التغطية الصحية الشاملة في جمهورية إيران الإسلامية }
\end{aligned}
$$

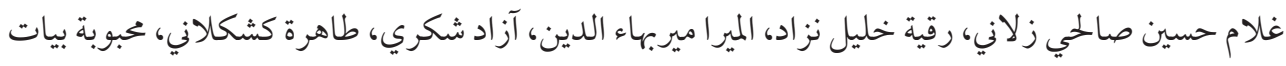

$$
\begin{aligned}
& \text { الخلاصة }
\end{aligned}
$$

$$
\text { الخلفية: من المستحيل تحقيق تغطية صحية شاملة دون وجود قوى عاملة كافية ومؤهَّلة ومُتحمِّسة. }
$$

المدف: وصف الكيفية التي صاغ بها قطاع الصحة الإيراني استراتيجيات موارده البشرية لتحقيق التغطية الصحية الشاملة.

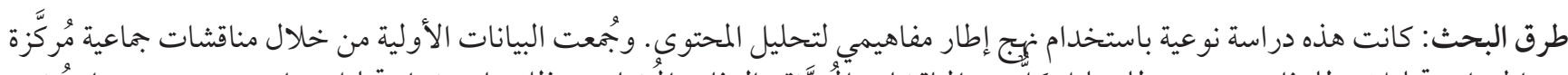

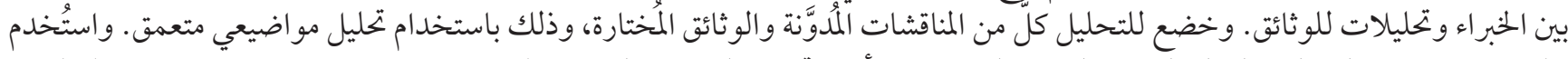

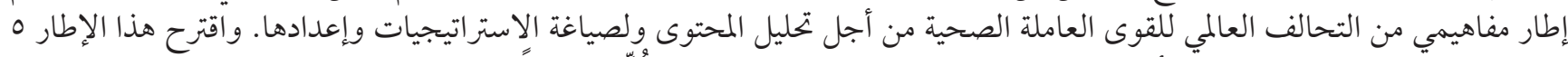

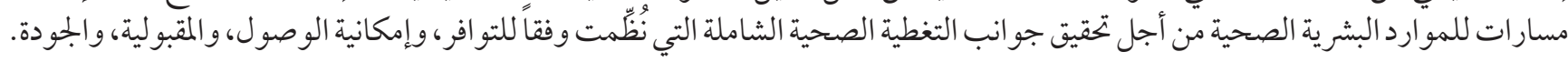

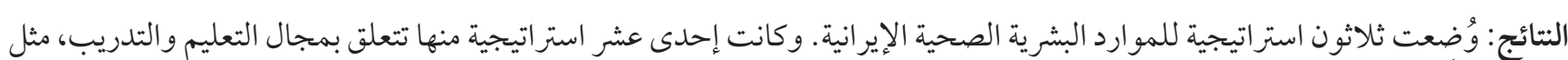

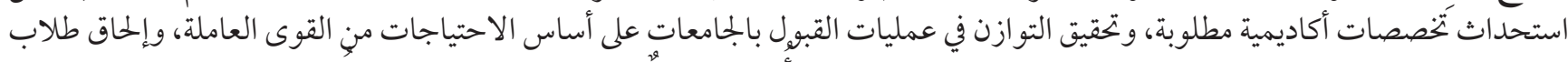

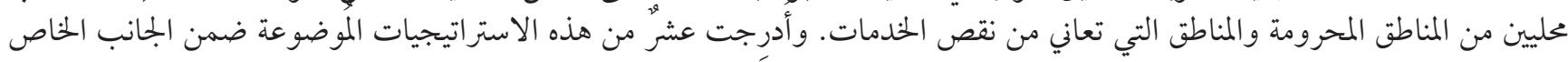
بإمكانية الوصول إلى القوى العاملة.

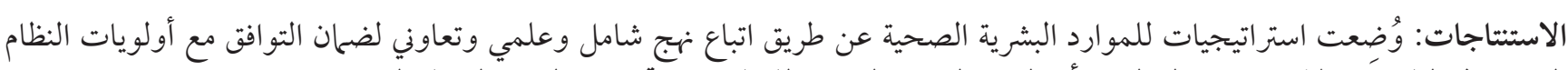

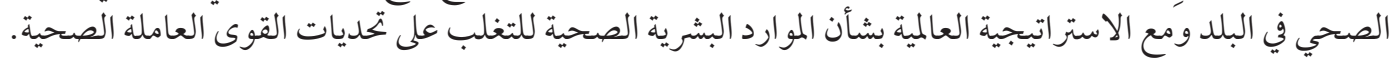

\section{References}

1. Chen L, Evans T, Anand S, Boufford JI, Brown H, Chowdhury M et al. Human resources for health: overcoming the crisis. Lancet, 2004:364(9449):1984-90. https://doi.org/10.1016/So140-6736(04)17482-5 PMID:15567015

2. United Nations. Report of the United Nations Conference on Environment and Development, Rio de Janeiro, 3-14 June 1992 (A/ CONF.151/26 (Vol. I) (http://www.un.org/documents/ga/conf151/aconf15126-1annex1.htm, accessed 30 August 2018).

3. Corvalán CF, Kjellström T, Smith KR. Health, environment and sustainable development: identifying links and indicators to promote action. Epidemiology. 1999 Sep;10(5):656-60. https://doi.org/10.1097/00001648-199909000-00036 PMID:10468446

4. Backman G, Hunt P, Khosla R, Jaramillo-Strouss C, Fikre BM, Rumble C, et al. Health systems and the right to health: an assessment of 194 countries. Lancet. 2008 Dec 13;372(9655):2047-85. https://doi.org/10.1016/So140-6736(08)61781-X PMID:19097280

5. Hall JJ, Taylor R. Health for all beyond 2000: the demise of the Alma-Ata Declaration and primary health care in developing countries. Med J Aust. 2003 Jan 6;178(1):17-20. PMID 12492384

6. Von Schirnding Y. Health and sustainable development: can we rise to the challenge? Lancet, 2002 Aug 24;24;360(9333):632-7. PMID 12241950

7. Taylor AL, Dhillon IS. The WHO Global Code of Practice on the International Recruitment of Health Personnel: the evolution of global health diplomacy. Georgetown Law Faculty Publications and Other Works, 2011 (http://scholarship.law.georgetown.edu/ facpub/733, accessed 30 August 2018).

8. Hasani SA, Mobaraki H. Bayat M, Mafimoradi S. Right place of human resource management in the reform of health sector. Iran J Public Health. 2013;42(1):56-62.

9. Dussault G, Dubois CA. Human resources for health policies: a critical component in health policies. Hum Resour Health. 2003 
Apr 14;1(1):1. https://doi.org/10.1186/1478-4491-1-1 PMID:12904254

10. Hongoro C, McPake B. How to bridge the gap in human resources for health. Lancet. 2004 Oct 16-22;364(9443):1451-6. https:// doi.org/10.1016/S0140-6736(04)17229-2 PMID:15488222

11. Cometto G, Witter S. Tackling health workforce challenges to universal health coverage: setting targets and measuring progress. Bull World Health Organ. 2013 Nov 1;91(11):881-5. https://doi.org/10.2471/BLT.13.118810 PMID:24347714

12. Sousa A, Scheffler RM, Nyoni J, Boerma T. A comprehensive health labour market framework for universal health coverage. Bull World Health Organ. 2013 Nov 1;91(11):892-4. https://doi.org/10.2471/BLT.13.118927 PMID:24347720

13. Tanahashi, T. Health service coverage and its evaluation. Bull World Health Organ, 1978. 56(2):295-303. PMID 96953

14. Toebes B. The right to health. In: Eide A, Krause C, Rosas A, editors. Economic, social and cultural rights, 2nd edition. Kluwer Law International; 2001:169-90.

15. Campbell J, Buchan J, Cometto G, David B, Dussault G, Fogstad H, et al. Human resources for health and universal health coverage: fostering equity and effective coverage. Bull World Health Organ. 2013 Nov 1;91(11):853-63. https://doi.org/10.2471/ BLT.13.118729 PMID 24347710

16. Russo G, McPake B, Fronteira I, Ferrinho P. Negotiating markets for health: an exploration of physicians' engagement in dual practice in three African capital cities. Health Policy Plan. 2014 Sep;29(6):774-83. https://doi.org/10.1093/heapol/czto71 PMID 24077880

17. Human resources for universal health coverage: a template for eliciting commitments. Jul 4, 2013 (http://www.who.int/workforcealliance/forum/2013/template_HRH_commitments_8July2013.pdf, accessed 30 August 2018).

18. Giorgio C, Courcelles S.d, Afzal M, Ahmed F, Codjia L, Gedik G et al. Analysis of the commitments made by national governments of 57 countries at the Third Global Forum on human resources for health. World Health Organization, 2015 (http://www.who.int/ workforcealliance/about/Ag_5.1_Analysis_HRH_commitments_10Apr15.pdf?ua=1, accessed 30 August 2018).

19. Ministry of Health and Medical Education. Human resources for health strategic plan. Tehran: MoHME; 2003 (in Persian).

20. Ministry of Health and Medical Education Policy Making Committee. Iranian Health System Reform plan: main process of the map. Tehran: MoHME; 2010 (in Persian).

21. Khunti K. Use of multiple methods to determine factors affecting quality of care of patients with diabetes. Fam Pract. 1999 Oct;16(5):489-94. https://doi.org/10.1093/fampra/16.5.489 PMID 10533945

22. Patton MQ. Enhancing the quality and credibility of qualitative analysis. Health Serv Res. 1999 Dec;34(5 Pt 2):1189-208.

23. Patton MQ. Qualitative research. Wiley Online Library; 2005 (https://doi.org/10.1002/0470013192.bsa514).

24. Dussault G, Badr E, Haroen H, Mapunda M, Mars AS, Pritasari K, et al. Follow-up on commitments at the Third Global Forum on Human Resources for Health: Indonesia, Sudan, Tanzania. Hum Resour Health. 2016;14(1):16. https://doi.org/10.1186/s12960-0160112-0

25. Global strategy on human resources for health: workforce 2030. Geneva: World Health Organization; 2016 (http://www.who.int/ hrh/resources/global_strategy_workforce2030_14_print.pdf?ua=1, accessed 30 August 2018).

26. Cometto G, Tulenko K, Muula AS, Krech R. Health workforce brain drain: from denouncing the challenge to solving the problem. PLoS Med. 2013;10(9):e1001514. https://doi.org/10.1371/journal.pmed.1001514 PMID 24068895

27. Stewart J, Clark D, Clark PF. Migration and recruitment of healthcare professionals: causes, consequences and policy responses. Policy Brief, 2007 Aug;7:1-8 (http://www.hwwi.org/uploads/tx_wilpubdb/PB07_Health.pdf, accessed 30 August 2018).

28. Hall TL. Why plan human resources for health. Human Resources for Health Development Journal. 1998;2(2):77-86. (http://www. who.int/hrh/en/HRDJ_2_2_01.pdf, accessed 4 September 2018).

29. Health workforce policies in OECD countries: right jobs, right skills, right places. Paris: Organisation for Economic Co-operation and Development; 2016 (http://www.oecd.org/publications/health-workforce-policies-in-oecd-countries-9789264239517-en.htm, accessed 30 August 2018).

30. Niezen MG, Mathijssen JJ. Reframing professional boundaries in healthcare: a systematic review of facilitators and barriers to task reallocation from the domain of medicine to the nursing domain. Health Policy. 2014 Aug;117(2):151-69. https://doi. org/10.1016/j.healthpol.2014.04.016 PMID 24857559

31. Campbell J, Dussault G, Buchan J, Pozo-Martin F, Guerra Arias M, Leone C, et al. A universal truth: no health without a workforce. Forum Report, Third Global Forum on Human Resources for Health, Recife, Brazil. Geneva: Global Health Workforce Alliance and World Health Organization; 2013 (http://www.who.int/workforcealliance/knowledge/resources/GHWA_AUniversalTruthReport.pdf, accessed 30 August 2018).

32. Frenk J, Chen L, Bhutta ZA, Cohen J, Crisp N, Evans T et al. Health professionals for a new century: transforming education to strengthen health systems in an interdependent world. Lancet. 2010 Dec 4;376(9756):1923-58. https://doi.org/10.1016/So1406736(10)61854-5 PMID 21112623 